\title{
深さに比して相対的に大きな半径を有する球圧力源による地表面変位
}

\author{
一有限要素法による計算一
}

\author{
坂井孝行 (気象研究所地震火山研究部) ・ 山本哲也 ${ }^{*}$ (気象庁) \\ 福井敬一 (気象研究所地震火山研究部) ・藤原健治 (気象庁) \\ 高木朗充 (気象研究所地震火山研究部) ・ 中禮正明* (新潟地方気象台) \\ * 現所属 : 地磁気観測所
}

\section{Surface Displacement by Spherical Pressure Sources of relatively Large Radius compared with Those Depth}

\section{- Calculation by Finite Element Method -}

\author{
by \\ Takayuki Sakai ${ }^{1}$, Tetsuya Yamamoto ${ }^{2 *}$, Keiichi Fukui ${ }^{1}$, Kenji Fujiwara $^{2}$, \\ Akimichi Takagi ${ }^{1}$ and Masaaki Churei ${ }^{3 *}$ \\ 1. Seismology and Volcanology Research Department, Meteorological Research Institute, Tsukuba, Japan \\ 2. Japan Meteorological Agency, Tokyo, Japan \\ 3. Niigata Local Meteorological Observatory, Niigata, Japan \\ * Present affiliation: Magnetic Observatory, Ishioka, Japan
}

(Received June 16, 2006; Accepted February 20, 2007; Published July 10, 2007)

\begin{abstract}
Mogi-Yamakawa's model (or Mogi's model) has often been used to explain crustal deformation observed around volcanoes. This model is based on an analytical solution derived by Yamakawa (1955), which only holds good under the restricted condition that a small enough spherical pressure source exists at some depth within a semi-infinite homogeneous elastic body. However, there have been hardly any quantitative investigations of the application limit of this solution when $a / D$ ( $a$ : radius of the sphere, $D:$ depth of the sphere) increases. McTigue (1987) modified Yamakawa's solution so as to hold good even for large $a / D$. However, there have been no quantitative investigations of the application limit when $a / D$ increases for this solution either. Therefore, we created large $a / D$ numerical models using the finite element method (FEM) and found numerical solutions of surface deformation. Comparison with FE analyses clarified the limits of application of these two analytical solutions. For example, the values of $a / D$ that agree with FE analyses within $1 \%$ are 0.22 for Yamakawa's solution and 0.45 for McTigue's solution. These two analytical solutions may hold precisely with smaller $a / D$ values. However, the discrepancy between these two solutions and FE analysis gradually increases when $a / D$ exceeds these values. In contrast, if $D$ and $a$ are determined by applying Yamakawa's solution to results of FE analyses, $D$ is found to be determined much shallower than the true value, while $a$ is determined with relative precision. Therefore, $\Delta V$ (volume change of the spherical pressure source) may also be estimated with relative precision.
\end{abstract}

Corresponding author: Takayuki Sakai

Meteorological Research Institute,

1-1 Nagamine, Tsukuba, Ibaraki 305-0052, Japan.

E-mail: tsakai@mri-jma.go.jp 


\section{1.はじめに}

火山における地款変動を解釈するモデルとして、従 来、いわゆる「茂木-山川モデル」（または、単に「茂木 モデル」）が多く用いられてきた。このモデルは、山川

（1955）が導出した、地下の球圧力源による地表面変 位の解析解（以下「山川の解」）を、茂木（1957）が桜 島の大正大噴火（1914 年）前後の姶良カルデラ周辺の 地殼変動に適用したことからそう呼ばれている。

山川の解は、深さに対して充分小さな球圧力源が半 無限均質弾性体内に存在するという、非常に限定され た条件下においてのみ精度良く成立する（山川，1955）。 一方、現実の火山においては、地表面上に突出する火 山地形が存在するため、山川の解の前提条件はそもそ も完全には成り立たないほか、ある大きさを有する球 圧力源が非常に浅い場所に存在するような場合も想定 されうる。しかしながら、球圧力源の半径 $a$ と中心深 さ $D$ との比がどの程度の場合まで山川の解が精度良く

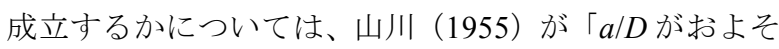
0.1 以下ならばこの解は充分に良い近似を与える」と記 しているものの、 $a / D$ が 0.1 より大きくなった場合の解 の精度についてはその後も定量的な検証がほとんど行 われないまま、山川の解が実際の観測データに広く適 用され、火山直下の圧力源の深さや体積変化量等の推 定が行われているのが現状である。

一方、McTigue（1987）は、 $a / D$ が大きい場合にも精 度良く成立するよう、山川の解に高次項を付け加えた 解析解（以下「McTigueの解」）を提案した。しかしな がら、この McTigue の解についても、山川の解と同様 に、 $a / D$ がどの程度の大きさまで適用できるかについて の定量的な検証はこれまで行われていない。

そこで、本研究では、有限要素法 (finite element method, 以下「FEM $\rfloor$ ) を用いて、球圧力源半径が中心 深さに比して大きい場合について三次元の有限要素モ デル（finite element model, 以下「FEモデル」）を作成 し、有限要素解析 (finite element analysis, 以下「FE解 析」）を行って地表面変位の数值解を求める。その結果 を山川の解や McTigue の解と比較することにより、こ

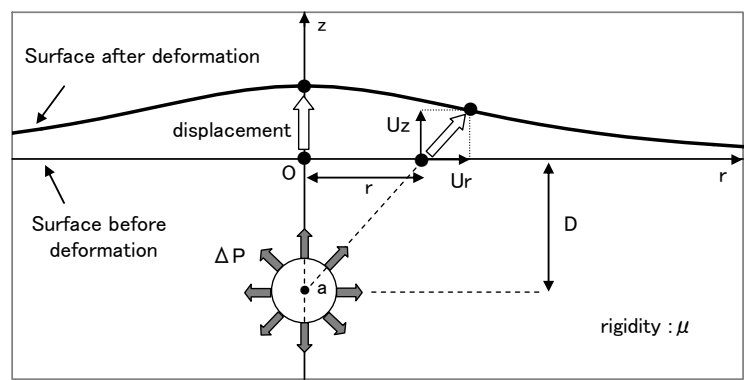

Fig. 1 Schematic illustration of Mogi-Yamakawa's model (or Mogi's model). $U_{z}$ and $U_{r}$ indicate vertical and horizontal displacements of the surface, respectively. $D$ and $a$ indicate depth and radius of the spherical pressure source, respectively. $r$ is the distance between a surface point and a point just above the center of the pressure source. $\Delta P$ indicates pressure change at the pressure source.
れら 2 つの解析解の適用限界を定量的に評価すると同 時に、球圧力源半径が深さに比して大きい場合の地表 面変位の特徵を明らかにする。

\section{2.山川の解と McTigue の解}

\section{1 山川の解}

山川（1955）によると、剛性率 $\mu$ の半無限均質弾性 体内に球核 (中心深さ $D$, 半径 $a$ ) が存在し、その表面 に $\Delta P$ の圧力変化が加わった場合（Fig.1）、球圧力源直 上からの水平距離が $r$ の地点にある地表面上の点の上 下変位 $U_{z}$ および radial 方向の水平変位 $U_{r}$ は次の解析解 で表される。ただし、ラメの定数 $\lambda$ は $\mu$ に等しいとする (従ってポアソン比 $\sigma=1 / 4$ )。また、山川の解による $U_{z}$ および $U_{r}$ であることを明確にするため、以下それぞ れ $U_{z(Y M K)}, U_{r(Y M K)}$ と表記する。

$$
\begin{aligned}
& U_{z(Y M K)}=\frac{3 a^{3} \Delta P}{4 \mu} \frac{D}{\left(D^{2}+r^{2}\right)^{3 / 2}} \\
& U_{r(Y M K)}=\frac{3 a^{3} \Delta P}{4 \mu} \frac{r}{\left(D^{2}+r^{2}\right)^{3 / 2}}
\end{aligned}
$$

なお、 $z$ 軸については、原論文では鉛直下向きを正と しているが、ここでは鉛直上向きを正として(1)式の符 号を変え、 $U_{z(Y M K)}>0$ の場合に地表面の隆起を表すこと とする。

この解は $a / D \ll 1$ の場合に、より具体的には $a / D \leqq 0.1$ の場合に、充分に良い近似を与えるが、 $a / D$ がそれより 大きくなっていくと、解の導出の際に仮定する鏡像の 影響によって解の精度は低下していく（山川，1955）。 (1)(2)式より、

$$
\frac{U_{z(Y M K)}}{U_{r(Y M K)}}=\frac{D}{r}
$$

という関係が成り立つことから、地表面上の任意の地 点は、Fig.1 に見られるように、球圧力源中心とその地 点とを結ぶ直線の延長線上に変位する。また、 $r=D$ に おいて $U_{z(Y M K)}$ と $U_{r(Y M K)}$ は等しくなる。 $r<D$ では $U_{z(Y M K)}$ $>U_{r(Y M K)}, r>D$ では $U_{z(Y M K)}<U_{r(Y M K)}$ となるため、 $r=D$ は $U_{z(Y M K)}$ と $U_{r(Y M K)}$ の大小関係が入れ替わる点となる。 つまり、 $U_{z(Y M K)}$ と $U_{r(Y M K)}$ は $r=D$ で交点を持つ。

次に、 $\Delta P>0$ (隆起) の場合の $U_{z(Y M K)}$ と $U_{r(Y M K)}$ の 最大值（それぞれ $U_{Z M A X(Y M K) ，} U_{r M A X(Y M K)}$ とする）につ いて見る。 $U_{z(Y M K)}$ は $r$ に関する単調減少関数であり、 $r$ $=0$ (球圧力源直上) において、最大值 


$$
U_{z M A X(Y M K)}=\frac{3 a^{3} \Delta P}{4 \mu} \frac{1}{D^{2}}
$$

を取る。一方、 $U_{r(Y M K)}$ が最大值を取る地点 $r_{M A X(Y M K)}$ は、 (2)式を $r$ で偏微分することにより、

$$
r_{M A X(Y M K)}=\frac{D}{\sqrt{2}} \cong 0.7071 D
$$

と導かれ、そこでの最大值 $U_{r M A X(Y M K)}$ は

$$
U_{r M A X(Y M K)}=\frac{3 a^{3} \Delta P}{4 \mu} \frac{1}{\sqrt{2}} \frac{1}{(3 / 2)^{3 / 2}} \frac{1}{D^{2}}
$$

となる。

$U_{z M A X}$ と $U_{r M A X}$ との比を以下 $\phi$ とし、山川解のそれ を $\phi_{(Y M K)}$ とすると、

$$
\begin{aligned}
\phi_{(Y M K)} & =U_{z M A X(Y M K)} / U_{r M A X(Y M K)} \\
& =\sqrt{2} \cdot(3 / 2)^{3 / 2} \cong 2.5981
\end{aligned}
$$

となる。

一方、この場合の球圧力源半径の変化量 $\Delta a$ は

$$
\Delta a=\frac{a \Delta P}{4 \mu}
$$

となる（萩原, 1977）。従って、球圧力源の体積変化量 $\Delta V$ は

$$
\begin{aligned}
\Delta V & =\frac{4}{3} \pi(a+\Delta a)^{3}-\frac{4}{3} \pi a^{3} \cong 4 \pi a^{2} \Delta a \\
& =\frac{\pi a^{3} \Delta P}{\mu}
\end{aligned}
$$

と表される。

\subsection{McTigue $の$ 解}

McTigue（1987）は、山川の解に $a / D$ の高次項を付 け加えることにより、 $a / D$ が大きい場合にも適用できる 解析解の導出を試みている。この McTigue の解の上下 変位 $U_{z}$ および水平変位 $U_{r}$ は次の解析解で表される。な お、McTigue の解による $U_{z}$ および $U_{r}$ であることを明確 にするため、それぞれ $U_{z(M c T)}, U_{r(M c T)}$ と表記する。

$$
\begin{aligned}
U_{z(M c T)}= & \varepsilon^{3}(1-\sigma) \frac{1}{\left(\rho^{2}+1\right)^{3 / 2}} \\
& -\varepsilon^{6}\left\{\frac{(1-\sigma)(1+\sigma)}{2(7-5 \sigma)} \frac{1}{\left(\rho^{2}+1\right)^{3 / 2}}\right. \\
& \left.-\frac{15(2-\sigma)(1-\sigma)}{4(7-5 \sigma)} \frac{1}{\left(\rho^{2}+1\right)^{5 / 2}}\right\} \cdots
\end{aligned}
$$

$U_{r(M c T)}=\varepsilon^{3}(1-\sigma) \frac{\rho}{\left(\rho^{2}+1\right)^{3 / 2}}$

$$
\begin{aligned}
& -\varepsilon^{6}\left\{\frac{(1-\sigma)(1+\sigma)}{2(7-5 \sigma)} \frac{\rho}{\left(\rho^{2}+1\right)^{3 / 2}}\right. \\
& \left.-\frac{15(2-\sigma)(1-\sigma)}{4(7-5 \sigma)} \frac{\rho}{\left(\rho^{2}+1\right)^{5 / 2}}\right\} \cdots
\end{aligned}
$$

ここで、 $\varepsilon=a / D, \rho=r / D$ であり、式全体は $\Delta P \cdot D / \mu$ で規 格化されている。また、 $z$ 軸は鈆直上向きが正である。

$(10)(11)$ 式に $\varepsilon=a / D, \rho=r / D$ を代入し、また、式全 体に $\Delta P \cdot D / \mu$ を掛けて規格化を取り払い、さらに、山川 の解に合わせて $\sigma=1 / 4$ とすると、(10)(11)式は

$$
\begin{aligned}
U_{z(M c T)}= & \frac{3 a^{3} \Delta P}{4 \mu} \frac{D}{\left(D^{2}+r^{2}\right)^{3 / 2}} \\
& -\frac{15 a^{6} \Delta P}{184 \mu} \frac{1}{D^{2}\left(D^{2}+r^{2}\right)^{3 / 2}} \\
& +\frac{315 a^{6} \Delta P}{368 \mu} \frac{1}{\left(D^{2}+r^{2}\right)^{5 / 2}}
\end{aligned}
$$

$$
\begin{aligned}
U_{r(M c T)}= & \frac{3 a^{3} \Delta P}{4 \mu} \frac{r}{\left(D^{2}+r^{2}\right)^{3 / 2}} \\
& -\frac{15 a^{6} \Delta P}{184 \mu} \frac{r}{D^{3}\left(D^{2}+r^{2}\right)^{3 / 2}} \\
& +\frac{315 a^{6} \Delta P}{368 \mu} \frac{r}{D\left(D^{2}+r^{2}\right)^{5 / 2}}
\end{aligned}
$$

と表現される。 $U_{z(M c T)}, U_{r(M c T)}$ とも、第 1 項 $((10)(11)$ 式の $\varepsilon^{3}$ 項）は山川の解に一致している。

山川の解の場合と同様に、 $U_{z(M c T)} / U_{r(M c T)}=D / r$ であ ることから、地表面上の任意の地点は球圧力源中心と その地点とを結ぶ直線の延長線上に変位する。また、 $r$ $=D$ において $U_{z(M c T)}$ と $U_{r(M c T)}$ が等しくなり、そこで大 小関係が入れ替わる(つまり $U_{z(M c T)}$ と $U_{r(M c T)}$ は $r=D$ で交点を持つ）ことも山川の解と同様である。 
(12)(13)式は次のように変形することも可能である。

$$
\begin{aligned}
U_{z(M c T)}= & \frac{3 a^{3} \Delta P}{4 \mu} \frac{D}{\left(D^{2}+r^{2}\right)^{3 / 2}}\left\{1-\frac{5 a^{3}}{46} \frac{1}{D^{3}}\right. \\
& \left.+\frac{105 a^{3}}{92} \frac{1}{D\left(D^{2}+r^{2}\right)}\right\} \cdots(14) \\
U_{r(M c T)}= & \frac{3 a^{3} \Delta P}{4 \mu} \frac{r}{\left(D^{2}+r^{2}\right)^{3 / 2}}\left\{1-\frac{5 a^{3}}{46} \frac{1}{D^{3}}\right. \\
& \left.+\frac{105 a^{3}}{92} \frac{1}{D\left(D^{2}+r^{2}\right)}\right\} \quad \cdots(15)
\end{aligned}
$$

従って、McTigue の解と山川の解との比は、 $U_{z}, U_{r}$ とも

$$
\begin{aligned}
& U_{z(M c T)} / U_{z(Y M K)}=U_{r(M c T)} / U_{r(Y M K)} \\
& =1-\frac{5 a^{3}}{46} \frac{1}{D^{3}}+\frac{105 a^{3}}{92} \frac{1}{D\left(D^{2}+r^{2}\right)}
\end{aligned}
$$

と表され、 $a / D$ だけではなく $r$ 関数でもある。 $a$ を $0.1 D$ から $0.9 D$ まで、 $0.1 D$ 刻みで変化させた場合の、rの変 化に伴う(16)式の変化の様子を Fig. 2 に示す。 $a / D$ が大 きいほど McTigue の解と山川の解との比が大きくなる ことは勿論だが、 $r$ が小いほど、即ち球圧力源の直上 に近いほどその比が大きくなることが分かる。

次に、 $\Delta P>0$ (隆起) の場合の $U_{z(M c T)}$ と $U_{r(M c T)}$ の最 大值（それぞれ $U_{z M A X(M c T)}, U_{r M A X(M c T)}$ とする）について 調べる。まず、 $U_{z(M c T)}$ については、(14)式から $r$ に関す る単調減少関数であることが容易に確かめられ、 $U_{z(Y M K)}$ と同様に $r=0$ (球圧力源直上)において最大值を 取る。その最大值 $U_{z M A X(M c T)}$ は、(12)式に $r=0$ を代入して

$$
\begin{aligned}
U_{z M A X(M c T)}= & \frac{3 a^{3} \Delta P}{4 \mu} \frac{1}{D^{2}} \\
& +\frac{285 a^{6} \Delta P}{368 \mu} \frac{1}{D^{5}}
\end{aligned}
$$

と表される。一方、 $U_{r(M c T)}$ が最大值を取る地点 $r_{M A X(M c T)}$ は、(13)式を $r$ で偏微分することにより、
と導かれる。このように、 $r_{M A X(M c T)}$ は、 $D$ のの関数で あった山川の解の $r_{M A X(Y M K)}$ （(5)式参照）と異なり、 $a$ の関数でもある。 $a$ を $0.01 D$ から $0.99 D$ まで変化させた 場合の、 $a$ と $r_{M A X(M c T)}$ との関係を Fig.3 に示す。 $r_{M A X(M c T)}$ は、 $a$ が小さい場合は $r_{M A X(Y M K)}((5)$ 式より $0.7071 D)$ に 一致するものの、 $a$ が大きくなるに従って小さくなり、 $a / D=0.9$ の場合には $0.5977 D$ まで小さくなる。つまり、 $U_{r(M c T)}$ は、 $a / D$ の増大につれて、より球圧力源直上に近 い地点で最大值を取るようになる。

$U_{r(M c T)}$ の最大值 $U_{r M A X(M c T)}$ は、(18)式を(13)式に代入 することによって求められる（式が長大になるため表 記は省略)。これと(17)式とから、McTigue の解の $U_{z M A X}$

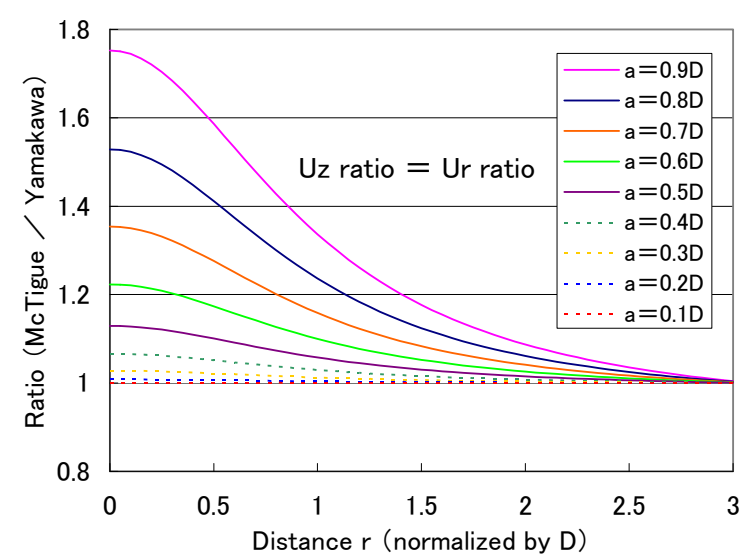

Fig. 2 Ratio of McTigue's solution to Yamakawa's solution. Radius $a$ is varied from $0.1 D$ to $0.9 D$. The ratio on $U_{z}$ of the two solutions and that on $U_{r}$ are equivalent for each $a$.

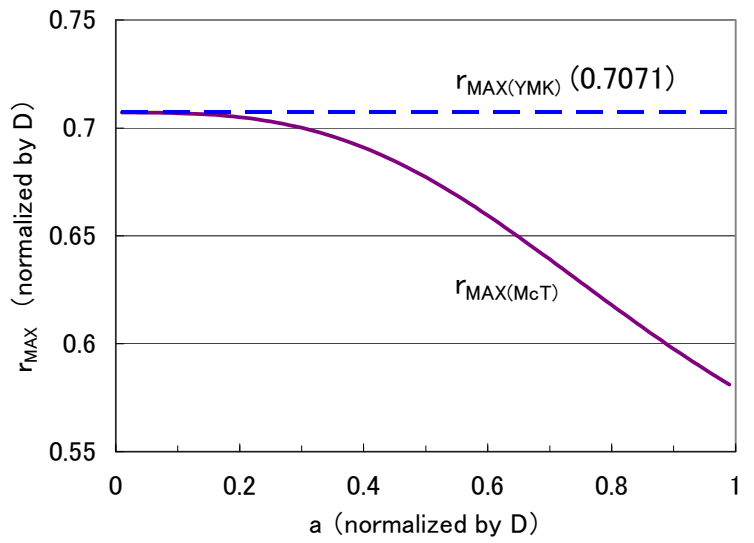

Fig. 3 Relationship between radius $a$ and $r_{M A X(M c T)}$ (the distance where $U_{r}$ of McTigue's solution reaches its maximum) a is varied from $0.01 D$ to $0.99 D$. While $a$ is small, $r_{M A X(M C T)}$ is equal to $r_{M A X(Y M K)}$ (the distance where $U_{r}$ of Yamakawa's solution reaches its maximum, $0.7071 D$ ).

$$
r_{M A X(M C T)}=\left\{\frac{138 D^{2}+615 \frac{a^{3}}{D}-\sqrt{\left(138 D^{2}+615 \frac{a^{3}}{D}\right)^{2}-\left(-552+60 \frac{a^{3}}{D^{3}}\right)\left(276 D^{4}+285 a^{3} D\right)}}{-552+60 \frac{a^{3}}{D^{3}}}\right\}^{1 / 2}
$$




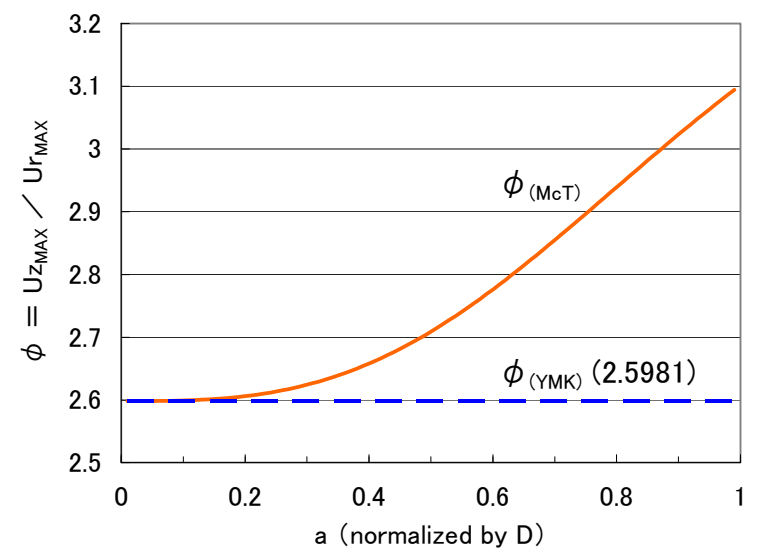

Fig. 4 Relationship between radius $a$ and $\phi_{(M C T)}$ (the ratio of $U_{z M A X}$ to $U_{r M A X}$ of McTigue's solution, where $U_{z M A X}$ and $U_{r M A X}$ indicate maximums of $U_{z}$ and $U_{r}$, respectively). While $a$ is small, $\phi_{(M C T)}$ is equal to $\phi_{(Y M K)}$ (the ratio of $U_{z M A X}$ to $U_{r M A X}$ of Yamakawa's solution, 2.5981). When $a$ increases, $\phi_{(M C T)}$ also increases gradually and finally exceeds 3 .

と $U_{r M A X}$ との比、 $\phi_{(M c T)}=U_{z M A X(M c T)} / U_{r M A X(M c T)}$ が求めら れる。 $\phi_{(Y M K)}($ 山川の解の $\phi)$ は定数 (2.5981) であっ たのに対し、 $\phi_{(M C T)}$ は $a$ の関数となる。 $\phi_{(M C T)}$ の $a$ によ る変化の様子を Fig.4に示す。 $a$ が小さい場合、 $\phi_{(M c T)}$ は $\phi_{(Y M K)}(=2.5981)$ に一致するが、 $a$ が大きくなるにつ れて $\phi_{(M c T)}$ の值は大きくなり、 $a / D$ が 0.88 以上では 3 を超えるようになる。

\section{FEM および今回作成した FE モデルの概要}

\subsection{FEM の概要と使用ソフトウェア}

FEM とは、物体の形状が複雑な場合など解析的に扱 うことが困難である場合に、その物体を仮想的に多数 の有限の大きさの要素 (element) に分割 (meshing, 以 下「メッシング」) して数值解を求める手法である。そ の際、要素内部の変位は形状関数 (shape function) と 呼ばれる関数によって補間され、それぞれの要素につ いての要素マトリックスを作成した後に、物体全体に ついての境界条件を組み込みつつ全ての要素マトリッ クスを統合した全体マトリックスを作成し、それを解 いて数值解が求められる。二次元 FE モデルの場合は三 角形要素や四角形要素が、また三次元 FE モデルの場合 は主として四面体要素や六面体要素がそれぞれ用いら れ、それらの多角形や多面体の頂点は節点（node）と 呼ばれる。

今回の三次元 $\mathrm{FE}$ モデルの作成および FE 解析には、 ANSYS, Inc. の FEM 汎用ソフトウェアである ANSYS Ver.7.0を用いた。三次元 FE モデルにおいて球面などの 曲面を扱う際は四面体要素が通常用いられる。今回は より高い計算精度が得られるよう、形状関数が座標の 二次関数で表される四面体要素（Fig.5）を用いた。こ の場合、Fig.5に見られるように、節点間に 6 個の中間 節点（midside node）が配置され、要素内のある点の例 えば $x$ 方向の変位 $u$ は次式で補間される（例えば、小 柴，1990)。

$$
\begin{aligned}
u= & u_{I}\left(2 L_{1}-1\right) L_{1}+u_{J}\left(2 L_{2}-1\right) L_{2} \\
& +u_{K}\left(2 L_{3}-1\right) L_{3}+u_{L}\left(2 L_{4}-1\right) L_{4} \\
& +4 u_{M} L_{1} L_{2}+4 u_{N} L_{2} L_{3}+4 u_{O} L_{1} L_{3} \\
& +4 u_{P} L_{1} L_{4}+4 u_{Q} L_{2} L_{4}+4 u_{R} L_{3} L_{4} \cdots
\end{aligned}
$$

ここで、 $u_{I} \sim u_{R}$ はそれぞれ節点 $I \sim L$ および中間節点 $M \sim R$ における $x$ 方向の変位であり、 $L_{1} \sim L_{4}$ は要素の 体積によって規格化された体積座標変数と呼ばれる座 標変数である。y方向および $z$ 方向の変位についても同 様にして補間が行われる。

\section{2 今回作成した FE モデルの概要}

FEM は主に工学分野で用いられる計算手法であり、 そこでは通常、機械製品や建造物などの解析対象全体 をモデリングして解析が行なわれる。一方、FEM を用 いて火山周辺の局所的な地殼変動を計算する場合には、 固体地球全体をモデリングする必要はないと考えられ、 固体地球の一部分のみを切り取ってモデリングするの が現実的である。その場合、モデル領域の大きさや境 界条件の設定が重要となることが予想されるが、坂 井・他（2007）は、圧力源の深さに対してモデル領域 を水平方向にも深さ方向にも充分大きく設定すれば、 モデル領域が限定されていることの影響をほとんど受 けずに高い計算精度が得られることを示した。そこで、 以下、坂井・他 (2007) に従って FE モデルを設定する。

固体地球表面の曲率は無視し、地表面を平面とする。 球圧力源の半径 $a$ を $1 \mathrm{~km}$ に固定し、 $a / D$ が $0.1,0.2, \cdots$, 0.9 となるよう、中心深さ $D$ を $10 \mathrm{~km}$ から次第に浅くし ていく (Table1 参照)。この球圧力源の周囲に円柱形の モデル領域を設定する。その場合、円柱モデル領域の 半径 $R$ および高さ $H$ を大きくするほどモデル領域中心 部での計算精度は高くなっていくが、反面、メッシン グが次第に困難になると共に節点数が増大し、計算時

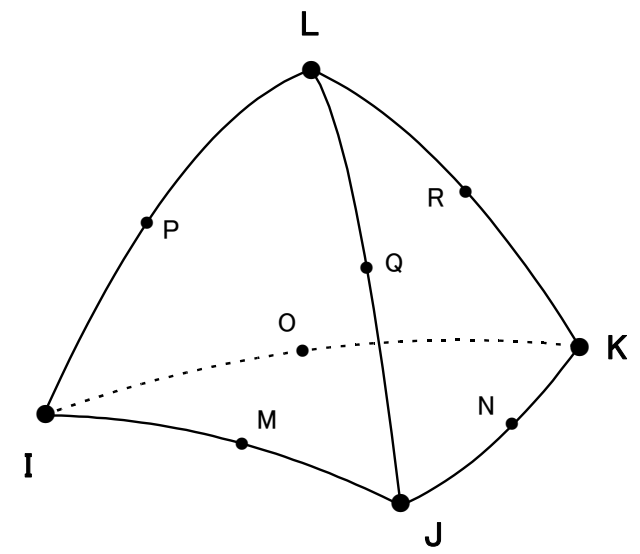

Fig. 5 Three-dimensional, 10-Node tetrahedral element used in this finite element analysis (FEA). I, J, K and L are nodes. M, N, O, P, Q and R are midside nodes. The shape function of this element is represented by a quadratic function. 
間も加速度的に増大していく。今回の解析では、全 9 モデルについてメッシングを行うことができたモデル 領域の中で最も大きな $R=H=700 \mathrm{~km}$ の円柱モデル領 域を設定することにした。 $a / D=0.1(a=1 \mathrm{~km}, D=10 \mathrm{~km})$

Table $1 \quad D$ and $a / D$ of each FE model analyzed in this study. Radius $a$ is fixed at $1 \mathrm{~km}$ in every FE model.

\begin{tabular}{c|c}
\hline \hline$D[\mathrm{~km}]$ & $a / D$ \\
\hline 10 & 0.1 \\
5 & 0.2 \\
3.33333 & 0.3 \\
2.5 & 0.4 \\
2 & 0.5 \\
1.66667 & 0.6 \\
1.42857 & 0.7 \\
1.25 & 0.8 \\
1.11111 & 0.9 \\
\hline \multicolumn{2}{c}{$(a=1 \mathrm{~km})$}
\end{tabular}

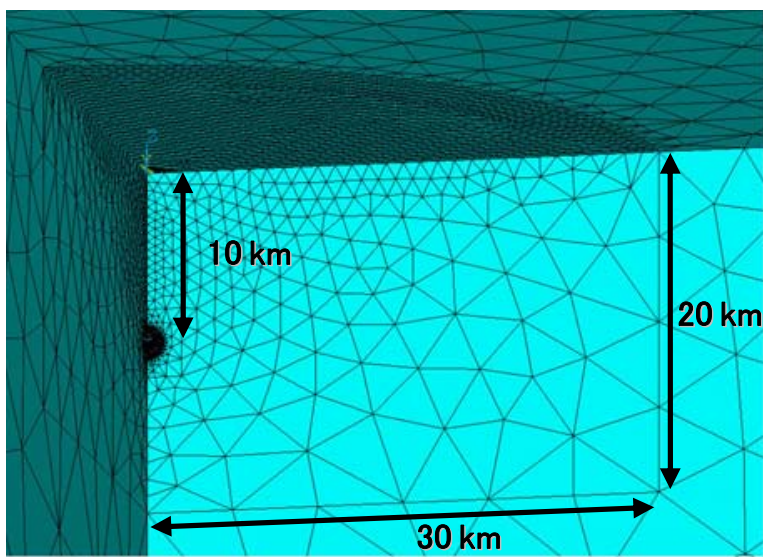

Fig. 6-1 Central part of " $a / D=0.1$ model", an FE model where radius $a$ and depth $D$ of the spherical pressure source are $1 \mathrm{~km}$ and $10 \mathrm{~km}$, respectively. Both radius $(R)$ and height $(H)$ of the columnar FE model region are set to $700 \mathrm{~km}$ in order to increase the precision of calculation.

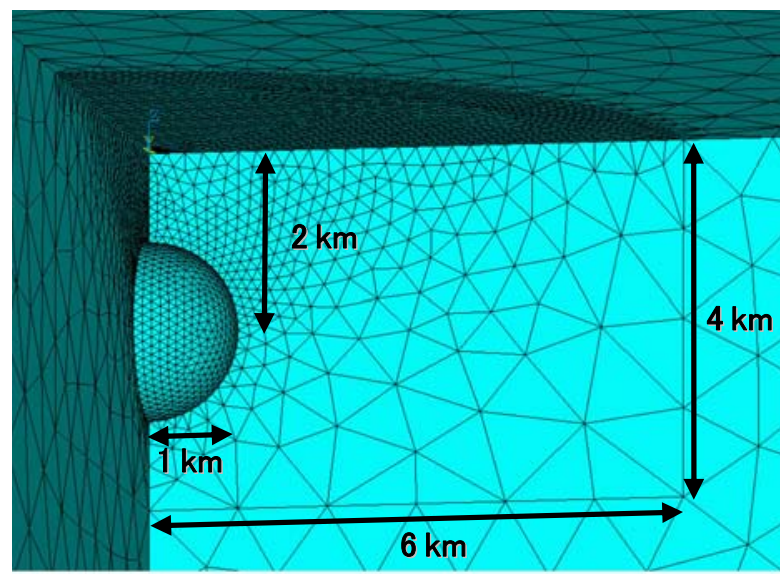

Fig. 6-2 Central part of " $a / D=0.5$ model", an FE model where radius $a$ and depth $D$ of the spherical pressure source are $1 \mathrm{~km}$ and $2 \mathrm{~km}$, respectively. Both $R$ and $H$ of the columnar FE model region are also set to $700 \mathrm{~km}$.
の場合のモデル中心部の拡大図を Fig.6-1に、また、 $a / D$ $=0.5(a=1 \mathrm{~km}, D=2 \mathrm{~km})$ の場合のモデル中心部の拡 大図を Fig.6-2 に示す。これらの円柱モデル領域は方位 角方向に 90 度に切断してあるが、今回扱うような軸対 称モデルの場合はこの 2 つの切断面に対称境界条件を 設定して FE 解析を行うことにより、要素数および節点 数を 360 度円柱モデルの場合の約 $1 / 4$ に減らしつつ、360 度円柱モデルと全く同じ解析結果を得ることができる。 円柱モデル領域の底面および外周面の境界条件は完全 固定（上下方向、水平方向の変位をいずれもゼロに拘 束）とした。

メッシングの設定は、球圧力源部分のメッシュサイ ズを $a(=1 \mathrm{~km})$ の $1 / 10$ の $100 \mathrm{~m}$ 程度とし、また、地表 面については、それぞれのモデルの $D$ の 3 倍までの距 離について、Dの $1 / 10$ の設定で細かくメッシングした。 モデルの媒質は均質かつ $\lambda=\mu$ （従ってポアソン比 $\sigma=$ 0.25）とし、剛性率 $\mu$ の值として、上部地殼の標準的な 值 $40 \mathrm{GPa}$ を用いた。この時、ヤング率は $100 \mathrm{GPa}$ とな る。球圧力源の表面に加わる圧力変化 $\Delta P$ は正 (外向き) とし、その大きさは、 $a / D=0.1$ モデルについては $1000 \mathrm{~atm}(=0.101325 \mathrm{GPa})$ とした。a/Dの大きなモデル については、 $\Delta P$ として 1000atm を与えると変位が非現 実的に大きな值になることもあるため、その大きさを 適宜調整した。

なお、 $a / D=0.1 \sim 0.9$ の $\mathrm{FE}$ モデルを作成する際、例 えば、 $R=H=700 \mathrm{~km}$ かつ $D=10 \mathrm{~km}$ とし、 $a$ を $1 \mathrm{~km}$ から $9 \mathrm{~km}$ まで大きくしていくといった方法も考えられるが、 モデル領域の大きさに比べて $a$ を大きくした場合には 球圧力源とモデル端との相互作用が強くなる可能性も 考えられ、それが計算精度にどのような影響を及ぼす か不明であるため、今回は上記のように $a$ を $1 \mathrm{~km}$ に固 定して $D$ を $10 \mathrm{~km}$ から次第に浅くしていくという方法 でモデルを作成した。

以下では、FE 解析結果による上下変位 $U_{z}$ および水 平変位 $U_{r}$ をそれぞれ $U_{z(F E M)}, U_{r(F E M)}$ と表記する。

\section{3 計算精度の確認}

上記の円柱モデル領域 $(R=H=700 \mathrm{~km})$ による計算 精度を確認するため、 $a / D=0.1 （=1 \mathrm{~km} / 10 \mathrm{~km})$ の場合 の $U_{z(F E M)}$ と $U_{r(F E M)}$ を、山川の解 $\left(U_{z(Y M K)}, U_{r(Y M K)}\right)$ と 併せて Fig.7-1 に示す。なお、横軸の距離 $r$ は $D$ の 3 倍 の $30 \mathrm{~km}$ までを表示し、 $U_{z(F E M)}$ と $U_{r(F E M)}$ は中間節点を 含めて $500 \mathrm{~m}$ 閒隔で示した。また、両者の比 $\left(U_{z(F E M)}\right.$ ) $\left.U_{z(Y M K)}, U_{r(F E M)} / U_{r(Y M K)}\right)$ を Fig.7-2 に示す。

今、 $a / D=0.1$ と、球圧力源半径は深さに比して充分 小さく、この場合は先述のように山川の解が充分精度 良く成り立っているため、Fig.7-2 に示した比は即ち FEM の計算精度（FEMによる山川の解の再現精度）を 表すことになる。 $U_{z}, U_{r}$ の計算精度とも、球圧力源直 上 $(r=0 \mathrm{~km})$ およびその近傍では 1 より僅かに大きく、 $r$ が大きくなるに従って徐々に 1 より小さくなっていく が、 $U_{r}$ については $r=30 \mathrm{~km}$ までの全範囲において 1.0028〜0.9967 の高い計算精度を実現しており、また、 $U_{z}$ についても $1.0019 \sim 0.9899$ と、最大誤差約 $1 \%$ の高 


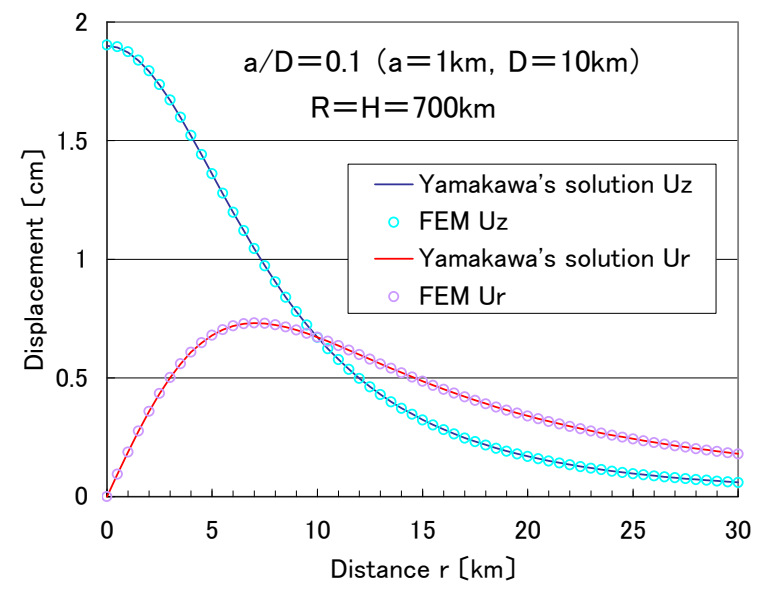

Fig. 7-1 Comparison of results of FEA of " $a / D=0.1$ model" $(a=1 \mathrm{~km}$ and $D=10 \mathrm{~km})$ and Yamakawa's solution. The horizontal axis (distance $r$ ) is shown as far as $30 \mathrm{~km}$. The results of FEA are plotted at intervals of $500 \mathrm{~m}$, including midside nodes, and are in agreement with Yamakawa's solution throughout the graph.

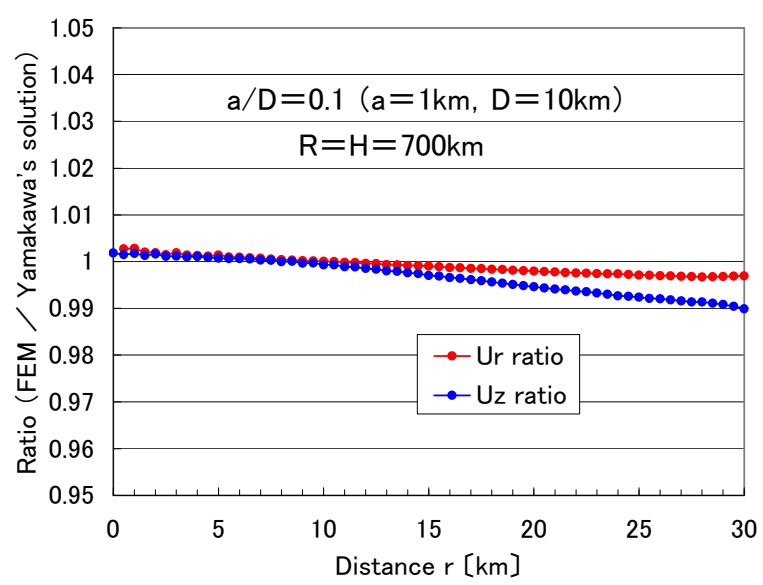

Fig. 7-2 Ratio of results of FEA of " $a / D=0.1$ model" to Yamakawa's solution. " $U_{z}$ ratio" means the ratio of $U_{z(F E M)}\left(U_{z}\right.$ of $\mathrm{FE}$ models $)$ to $U_{z(Y M K)} \quad\left(U_{z}\right.$ of $U_{z(F E M)}\left(U_{z}\right.$ of FE models) to $U_{z(Y M K)}\left(U_{z}\right.$ of
Yamakawa's solution), and " $U_{r}$ ratio" means that of $U_{r}$. These ratios hold near 1 throughout the graph, which indicates high precision of calculation.

い計算精度が確保されている。 $r$ の増加に伴う計算精度 の低下はモデル端の影響と考えられる（坂井・他, 2007)。 一方、モデル端の影響をほとんど受けず非常に高精度 の $\mathrm{FE}$ 解析結果が得られる球圧力源直上 $(r=0 \mathrm{~km})$ およ びその近傍において、比の值が 1 より僅かに（0.2\%程 度）大きくなっているのは、 $a / D$ を 0.1 と充分小さくし ても球圧力源半径の大きさの影響が僅かながら存在し、 山川の解が厳密には成立していないためと考えられる。 今回の $\mathrm{FE}$ 解析では、全てのモデルで $a=1 \mathrm{~km}$ かつ $R$ $=H=700 \mathrm{~km}$ と設定していることから、全モデルについ て Fig.7-2 と同程度の計算精度が成り立っていると考え られる。

なお、 $r$ が $10 \mathrm{~km}$ 以上になると $U_{z}$ の計算精度は $U_{r}$ に 比べて明らかに大きく低下するが、この理由について は現在のところ不明である（坂井・他，2007）。

\section{FE 解析結果と $2 つ$ つ解析解との比較}

前節のようにして作成した $a / D=0.1 \sim 0.9$ の各モデ ルの FE 解析結果を、山川の解および McTigue の解と比 較する。

ところで、FEモデルでは、各部の比率を保ちつつモ デル全体の大きさを変えた場合には相似則が成り立つ ことから、FE解析を行ったある具体的なモデルの諸量 をあるパラメータで規格化して一般化することが可能 である（坂井・他，2007）。そこで以下では、 $r$ および $a$ について、各モデルの具体的数值ではなく $D$ で規格 化した值で示すことにより、一般性を持たせた議論と する。

\subsection{FE 解析結果の概要}

今回計算した 9 例の FE モデル $(a / D=0.1 \sim 0.9)$ の うち 4 例のモデル $(a / D=0.3,0.5,0.7,0.9)$ について、 $U_{z(F E M)}$ と $U_{r(F E M)}$ を Fig.8-1(a) 8-4(a)に示す（距離 $r=$ $3 D$ まで、中間節点を含めて $0.05 D$ 間隔)。図中には山 川の解および McTigue の解も併せて示した。なお、縦 軸はそれぞれのグラフについて(4)式の $U_{z M A X(Y M K)}$ で規 格化して示した。

また、山川の解および McTigue の解の $U_{z}$ と $U_{r}$ それ ぞれについて、FE 解析結果との比を取ったグラフも Fig.8-1(b)〜8-4(b)に示した（ただし、 $r=0$ では 3 者いず れも $U_{r}=0$ となるため比は示していない)。それぞれの 解析解について、 $U_{z}$ の比と $U_{r}$ の比はほぼ重なり合って いる。

$a / D=0.1$ （Fig.7-1 参照）および 0.2 では 3 者の変位 はほぼ一致するが、 $a / D=0.3$ (Fig.8-1）になると山川の 解がそれ以外の 2 者と乘離し始める。これは、山川の 解が要請する「深さに対して充分小さな球圧力源」と いう前提条件が、 $a / D=0.3$ で既に成り立たなくなって いることを示す。さらに、McTigue の解も $a / D=0.5$

(Fig.8-2) 付近で FE 解析結果と分離し始める。

しかしながら、このように $a / D$ が大きくなった場合 に 3 者の変位の違いが目立つのは球圧力源に近い地点 のみであり、遠方では 3 者が比較的良く一致している ことも注目される。2つの解析解の $U_{z}, U_{r}$ とも、 $\mathrm{FE}$ 解析結果との比は $r=0$ において（ただし、 $U_{r}$ について は $r=0$ に最も近い $r=0.05 D$ において）最も 1 から離れ た值を取り、球圧力源から離れるにつれて徐々に 1 に 近付いていく。従って、遠方においては、 $a / D$ の大きさ が地表面変位に与える影響は小さく、2つの解析解と も比較的良く成り立つと言える（しかしながら、実際 の火山での地殼変動観測では、そのような遠方の変位 量の小さいデータはさほど重要ではないことが多い)。

ところで、 $a / D=0.9$ の場合（Fig.8-4）、 $r=1.2 D$ 以遠 において、McTigue の解と FE 解析結果との比が 1 より 僅かに大きくなっている。 $U_{z}$ について $r=1.65 D$ で比 が 1.017 と最大となり、また、 $U_{r}$ については $r=1.75 D$ で比の最大值 1.025 を取る。このような $2 \%$ 程度の差は、 Fig.7-2 に示した FEM の計算精度 $\left(U_{z}\right.$ で約 $1 \%, U_{r}$ で約 $0.3 \%$ ）に比べて有意に大きいことから、McTigue の解 

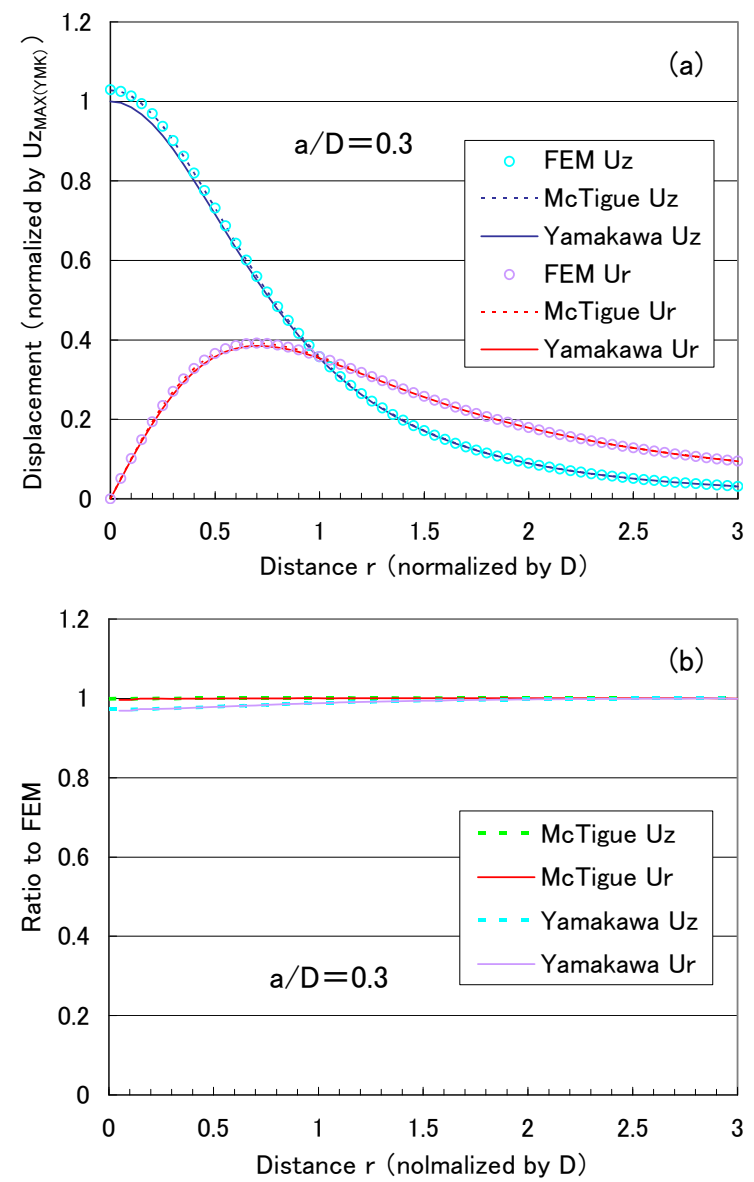

Fig. 8-1(a) Results of FEA of " $a / D=0.3$ model". Yamakawa's solution and McTigue's solution are also indicated. The horizontal axis is normalized by $D$, and the vertical axis by $U_{z M A X(Y M K)}\left(U_{z M A X}\right.$ of Yamakawa's solution, equation (4)).

(b) Ratio of Yamakawa's solution and McTigue's solution to results of FEA of " $a / D=0.3$ model".

の性質に起因するものと考えられる。これと同様のこ とは $a / D=0.8$ および 0.7 (Fig.8-3) の場合にも見られる。

\section{$4.2 U_{z(F E M)}$ と $U_{r(F E M)}$ の交点}

先に第 2 節で見たように、山川の解および McTigue の解の $U_{z}$ と $U_{r}$ は $r=D$ において交点を持つが、同様の 関係は FE 解析結果についても成立しているであろう か。

Fig.7-1 および Fig.8-1(a)〜8-4(a)上において、0.05D 間隔で離散的に与えられている $U_{z(F E M)}$ および $U_{r(F E M)}$ を 曲線として捉えると、両者の交点は $r=D$ 付近に存在す る様子が見て取れる。

これを定量的に確かめるため、(19)式の形状関数を 使用する ANSYS の補間ツールを利用して、各節点 (中 間節点を含めて $0.05 D$ 間隔） での $U_{z(F E M)}$ および $U_{r(F E M)}$ から $0.0001 D$ 間隔で值を補間し、 $U_{z(F E M)}$ と $U_{r(F E M)}$ との 差の絶対值が最も小さくなる地点を両者の交点と見な した。その結果、それらの地点の距離 $r$ は各モデルの $D$ と $0.1 \%$ 以内の高い精度で一致した。従って、 $a / D$ の大 きな球圧力源が現実に地下に存在する場合も、 $U_{z}$ と $U_{r}$
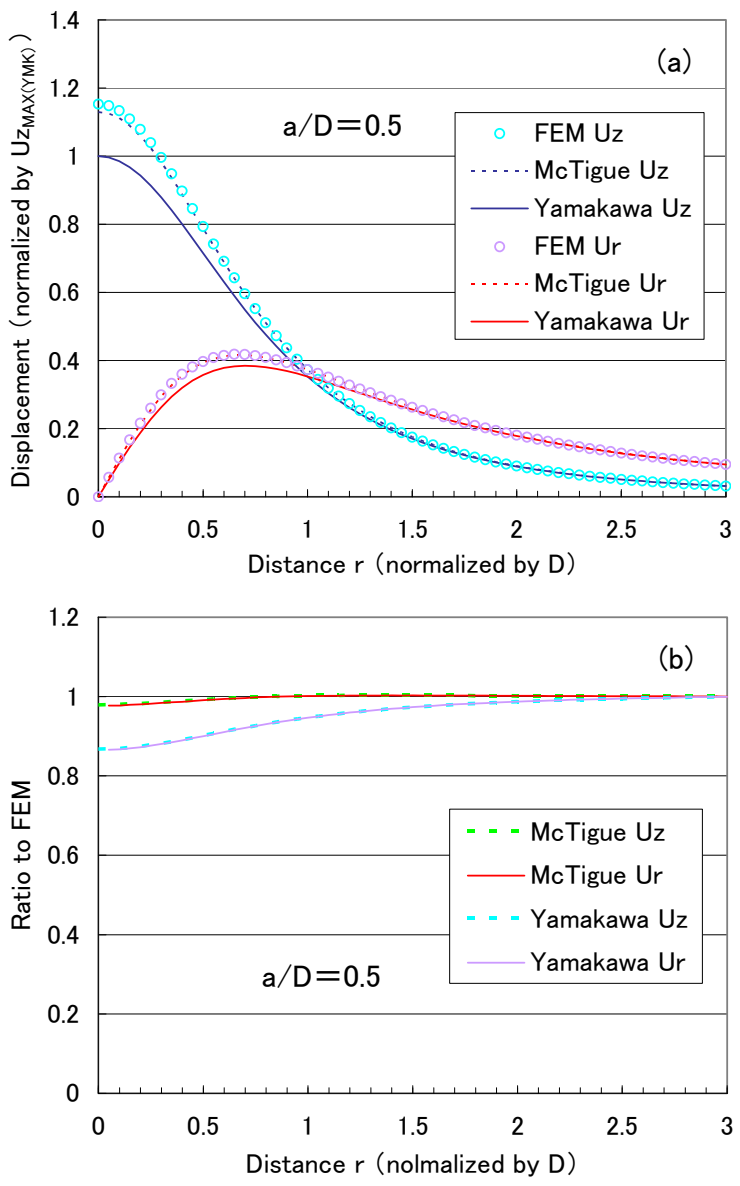

Fig. 8 -2(a)(b) For $a / D=0.5$.

は $r=D$ において交点を持つことになる（ただし、地表 面が平面であり、かつ媒質が均質である場合)。あるい は、もし $U_{z}$ と $U_{r}$ の大きさが等しくなる地点があれば、 その地点の球圧力源直上からの距離 $r$ が $D$ に等しくな る。

\section{3 地表面上の点の変位ベクトルの方向}

第 2 節で見たように、山川の解および McTigue の解 では $U_{z} / U_{r}=D / r$ という関係が成り立ち、このことは、 地表面上の任意の地点は球圧力源中心とその地点とを 結ぶ延長線上に変位することを意味する。一方、FE解 析結果についても同様の関係が成り立つならば、それ は $a / D$ の大きな球圧力源が現実に存在する場合にその 中心深さを推定する上で非常に有用な性質と考えられ る。そこで、各モデルの $U_{z(F E M)} / U_{r(F E M)}$ と $D / r$ がどの程 度一致しているか定量的に調査する。

$a / D=0.5$ の場合の $U_{z(F E M)} / U_{r(F E M)}$ と $D / r$ との比較を Fig.9 に示す。 $r=3 D$ までの全範囲で、 $U_{z(F E M)} / U_{r(F E M)}$ は $D / r$ と $0.3 \%$ 以内の高い精度で一致している。他の 8 モ デルについても同様の結果が得られ、 $U_{z(F E M)} / U_{r(F E M)}$ は $D / r$ と最大でも $1 \%$ 以内で一致した。この $1 \%$ の誤差は FEM の計算精度（Fig.7-2 参照）の影響と考えられ、従 って、 $a / D$ の大きな球圧力源が現実に存在する場合にも、 

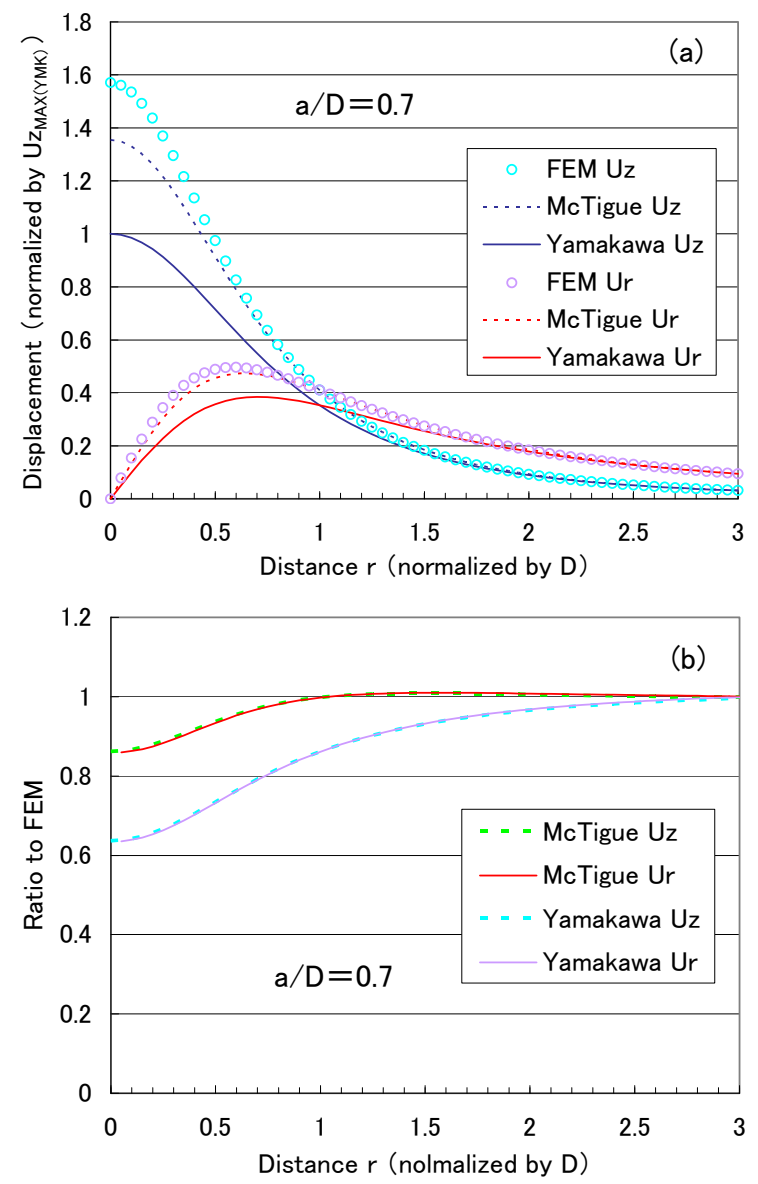

Fig. 8-3(a)(b) For $a / D=0.7$.

地表面上の任意の地点は球圧力源中心とその地点とを 結ぶ延長線上に変位すると言える。

よって、地表面が平面であり、かつ媒質が均質であ る場合には、 $a / D$ の小にかかわらず、任意の地点の変 位ベクトルの延長線上（地表面隆起の場合は逆向き） に球圧力源の中心が存在することになる。さらに、地 表面上の 2 点において変位ベクトルが得られれば、そ れらの延長線が交わった点が球圧力源の中心となる。

なお、Fig.8-1(b)〜8-4(b)において、それぞれの解析 解について $U_{z}$ の比と $U_{r}$ の比がほぼ重なり合っている ことも、FE モデルの各地点の変位ベクトルは 2 つの解 析解の変位ベクトルをほぼ同じ方向に延伸したもので あることを示している。また、それらの比が球圧力源 直上（ $r=0 ）$ において最も 1 から離れた值を取り、球 圧力源から離れるにつれて徐々に 1 に近付いていくこ とは、変位ベクトルの延伸の度合いが球圧力源直上に おいて最も大きく、距離が離れるにつれて徐々に小さ くなっていくことを示す。これは、球圧力源直上は地 下の球圧力源の表面から最も近い地表面上の点であり、 $a / D$ が大きいことの影響をそこが最も受けやすいため と考えられる。

\section{$4.4 U_{z}$ および $U_{r}$ の最大值の比較}

次に、FE 解析結果と山川の解および McTigue の解と
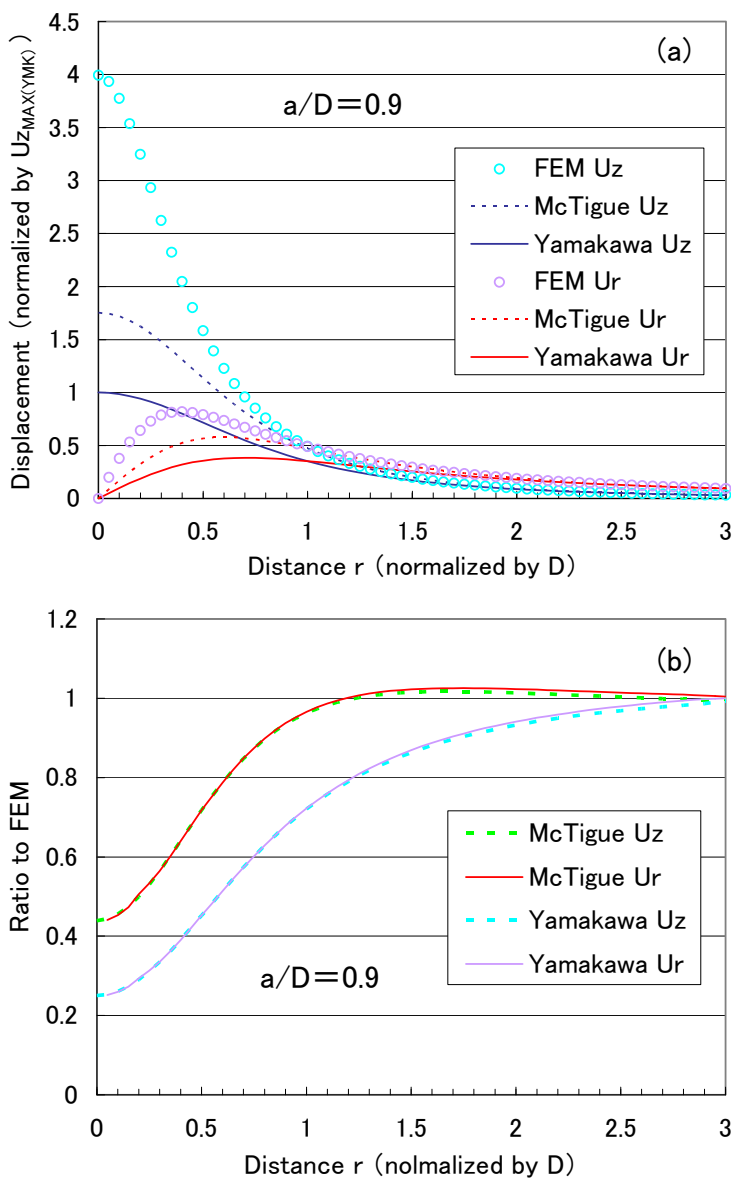

Fig. 8-4(a)(b) For $a / D=0.9$.

の比較をより詳しく行うため、それぞれの $U_{z}$ と $U_{r}$ の最 大值に注目する。

なお、FE解析結果については、4.2 節と同様に、(19) 式の形状関数を使用する ANSYS の補間ツールを利用 して、各節点 (中間節点を含めて $0.05 D$ 間隔) での $U_{z(F E M)}$ および $U_{r(F E M)}$ から $0.0001 D$ 間隔で值を補間し、その中 で最大となるものを最大值 $U_{Z M A X(F E M)}$ および $U_{r M A X(F E M)}$

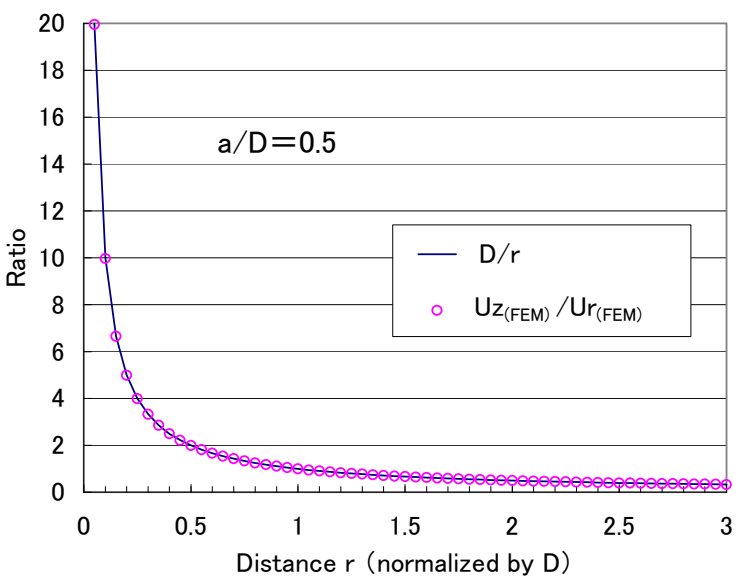

Fig. 9 Comparison of $U_{z(F E M)} / U_{r(F E M)}$ and $D / r$ for $a / D=0.5$ $\left(U_{z(F E M)}\right.$ and $U_{r(F E M)}$ mean $U_{z}$ and $U_{r}$ of FE model, respectively). $U_{z(F E M)} / U_{r(F E M)}$ agree with $D / r$ within $0.3 \%$ throughout the graph. 
とした。また、両者の比 $\left(U_{Z M A X(F E M)} / U_{r M A X(F E M)}\right)$ を $\phi_{(F E M)}$ とし、 $U_{r M A X(F E M)}$ が現れる地点を $r_{M A X(F E M)}$ とする。

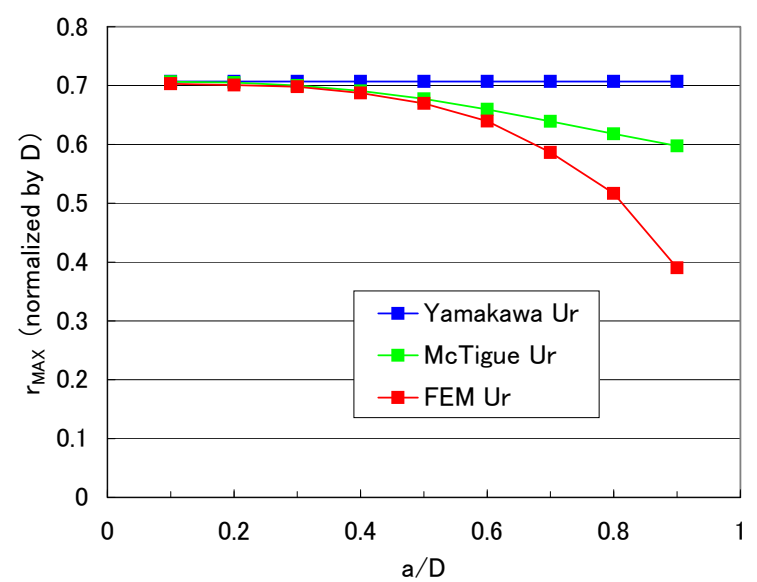

Fig. 10-1 Changes of $r_{M A X}$ (the distance where $U_{r}$ reaches its maximum) of Yamakawa's solution, McTigue's solution, and FE models with increasing $a / D$.

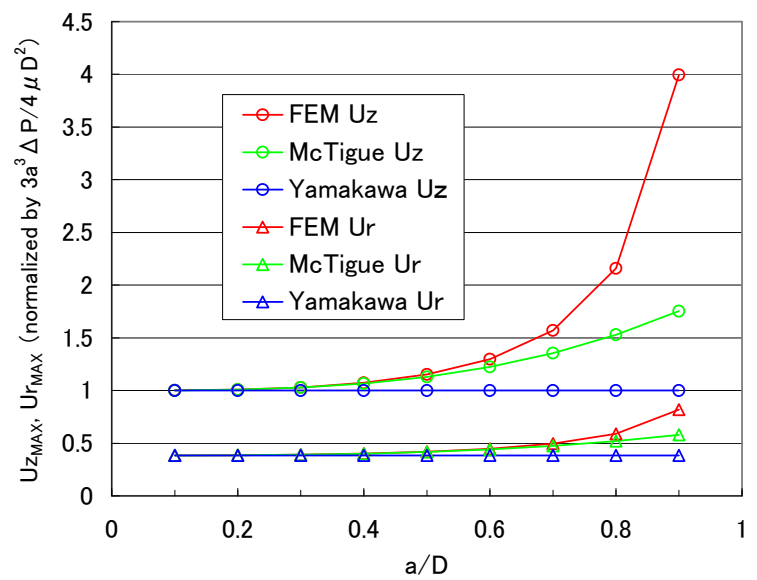

Fig. 10-2 Changes of $U_{z M A X}$ and $U_{r M A X}$ of Yamakawa's solution, McTigue's solution, and FE models with increasing $a / D$. The vertical axis is normalized by $U_{z M A X(Y M K)}$ for each $a / D$.

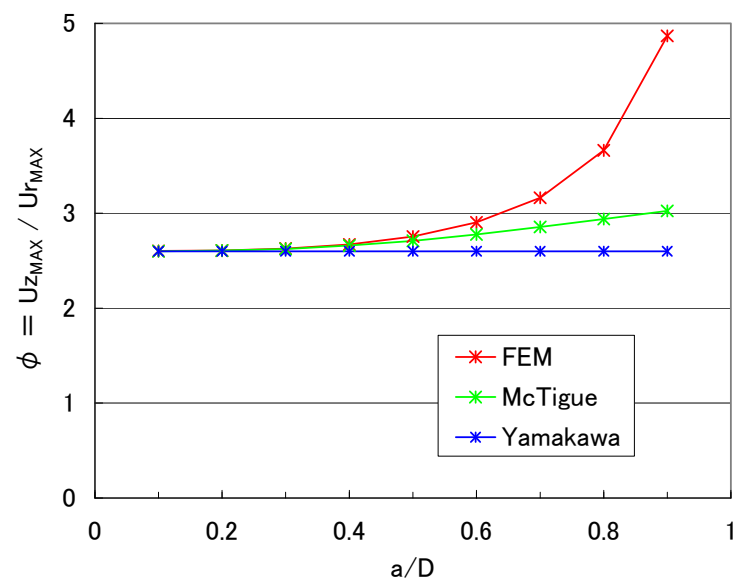

Fig. 10-3 Changes of $\phi$ (the ratio of $U_{z M A X}$ to $U_{r M A X}$ ) of Yamakawa's solution, McTigue's solution and FE models with increasing $a / D$.

\subsection{1 $U_{z}$ および $U_{r}$ が最大值を取る地点の比較}

最初に、3 者の $U_{z}$ および $U_{r}$ が最大值を取る地点に ついて見る。

$U_{z}$ については、 $U_{z(F E M)}$ は 2 つの解析解と同様、 $r=0$ (球圧力源直上) で最大值を取る。

一方、 $U_{r}$ が最大值を取る地点 $r_{M A X}$ は 3 者間で異なる。 $a / D$ の増大に伴う 3 者の $r_{M A X}$ の変化の様子を Fig. 10-1 に示す。 $r_{M A X(Y M K)}$ は $a / D$ にかかわらず $0.7071 D$ で一定で ある。一方、 $r_{M A X(F E M)}$ は、 $a / D=0.1$ および 0.2 の場合は $0.7071 D$ に $1 \%$ 以内で一致するが、 $a / D$ が 0.3 以上にな ると徐々に $0.7071 D$ より小さくなっていく。つまり、 $U_{r(F E M)}$ は、より球圧力源直上に近い地点で最大值を取 るようになる。 $a / D$ がさらに大きくなると $r_{M A X(F E M)}$ は急 速に減少していき、 $a / D=0.9$ の場合には $0.3903 D$ まで 小さくなる。これは $0.7071 D$ の $55 \%$ に相当する。一方、

$r_{M A X(M c T)}$ は、 $a / D=0.4$ までは $r_{M A X(F E M)}$ に $1 \%$ 以内で一致 するが、 $a / D$ がそれより大きくなると $r_{M A X(F E M)}$ の急速な 減少の様子を表すことができず、 $r_{M A X(F E M)}$ と $r_{M A X(Y M K)}$ と の間に位置する。例えば、 $a / D=0.9$ の場合には $r_{M A X(M c T)}$ は $0.5977 D$ であり、 $r_{M A X(Y M K)}$ の $85 \%, r_{M A X(F E M)}$ の $153 \%$ に相当する。

\subsection{2 $U_{z}$ および $U_{r}$ の最大値の比較}

次に、 3 者の $U_{z}$ および $U_{r}$ の最大值について見る。

$U_{z}$ の最大值 $U_{z M A X}$ および $U_{r}$ の最大值 $U_{r M A X}$ を 3 者で 比較した結果を Fig.10-2 に示す。なお、これらの值は いずれも(4)式の $U_{z M A X(Y M K)}$ で規格化した值である。そ のため、 $U_{Z M A X(Y M K)}$ の值は全て 1 となっている。また、 $U_{z M A X(M c T)}$ についての值は、(17)式と(4)式とより、

$$
U_{z M A X(M c T)} / U_{z M A X(Y M K)}=1+\frac{95}{92}\left(\frac{a}{D}\right)^{3}
$$

と表すことができる。なお、 $U_{r M A X(M c T)}$ についての值も 同様に解析的に表すことができるが、式が長大になる ため表記は省略する。

Fig.10-2 からは、 $U_{z M A X}, U_{r M A X}$ とも、a/Dが大きくな るほど 3 者の差が急速に開いていくことが分かる。つ まり、山川の解や McTigue の解は、 $a / D$ が大きくなっ た場合に実際には $U_{z M A X}$ および $U_{r M A X}$ が急速に大きくな っていく様子を表せないことが示されている。

$a / D$ が大きくなるにつれての 3 者の差の開き方は $U_{r M A X}$ よりも $U_{z M A X}$ の方が顕著である。これは、 Fig.8-1(b)〜8-4(b)でも見たように、 $U_{z}$ が最大值を取る 球圧力源直上 $(r=0)$ は 2 つ解析解と $\mathrm{FE}$ 解析結果と の比が最も 1 から離れる地点であるのに対し、 $U_{r}$ が最 大值を取る地点は球圧力源直上からある程度離れてお り、2つの解析解と FE 解析結果との比が球圧力源直上 よりも 1 に近いことによる。 


\subsection{3 $\phi$ の比較}

次に、 $\phi\left(U_{z M A X}\right.$ と $U_{r M A X}$ との比）を 3 者で比較した 結果を Fig.10-3 に示す。山川の解の場合、 $\phi_{(Y M K)}$ は先 述のように 2.5981 で一定であるが、McTigue の解およ び FE 解析結果では $a / D$ が大きくなると $\phi$ もきくなる。 $a / D$ が 0.5 より大きくなると $\phi_{(F E M)}$ は急速に大きくなる が、 $\phi_{(M c T)}$ はやはりその様子を表すことができず、 $\phi_{(F E M)}$ と $\phi_{(Y M K)}$ との間に位置する。

ところで、よく知られているように、実際の観測デ 一タに山川の解を適用する場合、 $a$ と $\Delta P$ との間にトレ ードオフが生じるため、一般にこれらのパラメータを 独立に決定することはできない。しかしながら、 $a / D$ の 大きな球圧力源が現実に地下に存在する場合、 $\phi$ は 2.5981 とは異なる值を取るはずであり、その值から $a / D$ を推定できるはずである。さらに、4.3 節で述べた変
位ベクトルを用いる方法で $D$ を求めることができれば $a$ を決定することができ、 $\mu$ の值を仮定すれば $\Delta P$ も決 定できることになる。

以上で示した最大地点、最大值、および $\phi$ に関する 結果を Table2 にまとめて示す。表中の FEM の值に対し てスプライン関数などを適用することにより、任意の $a / D$ についての諸量を算出することが可能であろう。な お、FEM では、同じソフトウェア上の同じモデルでも メッシングが異なれば解析結果に $0.2 \sim 0.3 \%$ 程度の違 いが生じることがあり、ここに示した值は必ずしも絶 対的な值ではないことに注意されたい。

\section{5 山川の解および McTigue の解の適用限界}

以上で示した結果を用い、山川の解および McTigue の解の適用限界について定量的に評価する。2つの解

Table 2 Distance $r$ where $U_{z M A X}$ and $U_{r M A X}$ appear, values of $U_{z M A X}$ and $U_{r M A X}$ (normalized by $U_{z M A X(Y M K)}$, equation (4)), and $\phi$ (the ratio of $U_{z M A X}$ to $U_{r M A X}$ ) of Yamakawa's solution, McTigue's solution, and FE models.

\begin{tabular}{c|ccc|ccc}
\hline \hline \multirow{2}{*}{$a / D$} & \multicolumn{2}{|c|}{$r$ of $U_{z M A X}$ point (normalized by $\left.D\right)$} & \multicolumn{2}{c}{$r$ of $U_{r M A X}$ point (normalized by $\left.D\right)$} \\
\cline { 2 - 7 } & Yamakawa & McTigue & FEM & Yamakawa & McTigue & FEM \\
\hline 0.1 & 0 & 0 & 0 & 0.7071 & 0.7068 & 0.7034 \\
0.2 & 0 & 0 & 0 & 0.7071 & 0.7050 & 0.7010 \\
0.3 & 0 & 0 & 0 & 0.7071 & 0.7000 & 0.6983 \\
0.4 & 0 & 0 & 0 & 0.7071 & 0.6909 & 0.6873 \\
0.5 & 0 & 0 & 0 & 0.7071 & 0.6772 & 0.6697 \\
0.6 & 0 & 0 & 0 & 0.7071 & 0.6595 & 0.6395 \\
0.7 & 0 & 0 & 0 & 0.7071 & 0.6391 & 0.5865 \\
0.8 & 0 & 0 & 0 & 0.7071 & 0.6180 & 0.5167 \\
0.9 & 0 & 0 & 0 & 0.7071 & 0.5977 & 0.3903 \\
\hline
\end{tabular}

\begin{tabular}{c|ccc|ccc}
\hline \hline \multirow{2}{*}{$a / D$} & \multicolumn{2}{|c|}{$U_{z M A X}($ normalized by equation (4)) } & \multicolumn{3}{c}{$U_{r M A X}($ normalized by equation (4)) } \\
\cline { 2 - 6 } & Yamakawa & McTigue & FEM & Yamakawa & McTigue & FEM \\
\hline 0.1 & 1 & 1.0010 & 1.0019 & 0.3849 & 0.3852 & 0.3852 \\
0.2 & 1 & 1.0083 & 1.0083 & 0.3849 & 0.3869 & 0.3869 \\
0.3 & 1 & 1.0279 & 1.0292 & 0.3849 & 0.3917 & 0.3918 \\
0.4 & 1 & 1.0661 & 1.0725 & 0.3849 & 0.4011 & 0.4014 \\
0.5 & 1 & 1.1291 & 1.1528 & 0.3849 & 0.4168 & 0.4185 \\
0.6 & 1 & 1.2230 & 1.2981 & 0.3849 & 0.4406 & 0.4472 \\
0.7 & 1 & 1.3542 & 1.5708 & 0.3849 & 0.4744 & 0.4967 \\
0.8 & 1 & 1.5287 & 2.1594 & 0.3849 & 0.5201 & 0.5896 \\
0.9 & 1 & 1.7528 & 3.9936 & 0.3849 & 0.5798 & 0.8203 \\
\hline
\end{tabular}

\begin{tabular}{c|ccc}
\hline \hline \multirow{2}{*}{$a / D$} & \multicolumn{3}{|c}{$\phi=U_{z M A X} / U_{r M A X}$} \\
\cline { 2 - 4 } & Yamakawa & McTigue & FEM \\
\hline 0.1 & 2.5981 & 2.5991 & 2.6012 \\
0.2 & 2.5981 & 2.6059 & 2.6058 \\
0.3 & 2.5981 & 2.6241 & 2.6270 \\
0.4 & 2.5981 & 2.6578 & 2.6720 \\
0.5 & 2.5981 & 2.7089 & 2.7547 \\
0.6 & 2.5981 & 2.7760 & 2.9025 \\
0.7 & 2.5981 & 2.8547 & 3.1622 \\
0.8 & 2.5981 & 2.9392 & 3.6625 \\
0.9 & 2.5981 & 3.0232 & 4.8682 \\
\hline
\end{tabular}




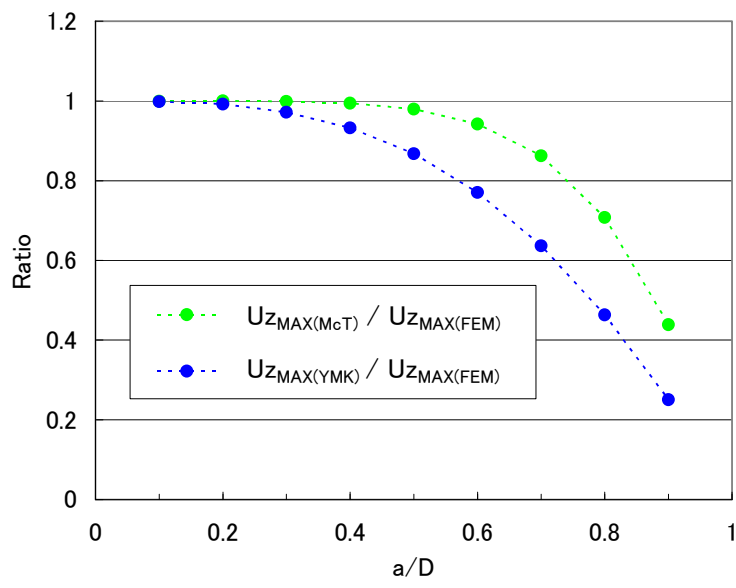

Fig. 11 Ratio of $U_{z M A X}$ of Yamakawa's solution and McTigue's solution to that of FE models for each $a / D$.

析解の適用限界の指標として、ここでは $U_{z M A X}$ を用いる。 これは、Fig.8-1(b)〜8-4(b)で示したように、 $U_{z}$ が最大 值を取る球圧力源直上 $(r=0)$ は 2 つの解析解と FE 解 析結果との比が最も 1 から離れる地点だからである。 ここはまた、モデル端の影響をほとんど受けず、非常 に高精度の FE 解析結果が得られる地点でもある（3． 3 節参照)。

$U_{z M A X(Y M K)}$ および $U_{z M A X(M c T)}$ について、それぞれ $U_{z M A X(F E M)}$ との比を取った結果を Fig.11に示す。いずれ も $a / D$ が大きくなるにつれて加速度的に小さくなって いくが、その度合いは当然のことながら高次項のない $U_{z M A X(Y M K)}$ の方が大きい。

これらのデータに 3 次のスプライン関数（自然スプ ライン）を適用し、 $U_{z M A X(Y M K)} / U_{z M A X(F E M)}$ および $U_{z M A X(M c T)} / U_{z M A X(F E M)}$ が $0.99,0.98, \cdots, 0.90$ になる a/Dの值を求めた。その結果を Table3 に示す。ただし、 スプライン補間に使用するデータ数は、補間する数值 を挟む 4 データ（前後 2 データずつ）とした。例えば、 $U_{z M A X(Y M K)} / U_{z M A X(F E M)}$ が 0.99 になる $a / D$ を決定する際に

Table 3 Values of $a / D$ where $U_{z M A X}$ of Yamakawa's solution and McTigue's solution become 0.99 to 0.90 times that of the FE model. These values were determined by applying a cubic spline function to values in Fig.11.

\begin{tabular}{c|c|c}
\hline \hline \multirow{2}{*}{ Ratio to $U_{z M A X(F E M)}$} & \multicolumn{2}{|c}{$a / D$} \\
\cline { 2 - 3 } & $U_{z M A X(Y M K)}$ & $U_{z M A X(M c T)}$ \\
\hline 0.99 & 0.2216 & 0.4538 \\
0.98 & 0.2853 & 0.4990 \\
0.97 & 0.3068 & 0.5438 \\
0.96 & 0.3411 & 0.5727 \\
0.95 & 0.3668 & 0.5901 \\
0.94 & 0.3868 & 0.6047 \\
0.93 & 0.4051 & 0.6246 \\
0.92 & 0.4250 & 0.6414 \\
0.91 & 0.4426 & 0.6555 \\
0.90 & 0.4582 & 0.6674 \\
\hline
\end{tabular}

は、 $a / D=0.1 \sim 0.4$ の 4 データを用いた。

Table3 より、例えば FE 解析結果と $1 \%$ 以内の精度で 一致する $a / D$ の大きさは、山川の解では約 0.22 , McTigue の解では約 0.45 となる。 $a / D$ がこれらの值より小さい 場合には、2つの解析解はそれぞれ充分精度良く成り 立つと言えよう。また、FE 解析結果との間に 3\%の誤 差を許容するならば、その時の $a / D$ は山川の解で約 0.31 , McTigue の解で約 0.54 であり、 $5 \%$ の誤差を許容するな らば、 $a / D$ は山川の解で約 0.37 , McTigue の解で約 0.59 となる。

\section{FE 解析結果に山川の解を適用した場合に推 定されるDおよび $a$}

火山周辺で観測された地殼変動データへの山川の解 の適用は、その簡便さから、地殼変動をもたらした圧 力源の深さを推定する際に極めて広く用いられている 手法である。この場合、圧力源の性状を $a / D \ll 1$ の球圧 力源と仮定していることになる。しかしながら、地下 に存在する球圧力源の $a / D$ が大きい場合、これまで見 たように、地表面変位は山川の解には一致しない。そ こで、今回の FE 解析結果に山川の解を適用して $D$ およ び $a$ を推定した場合に、それらが本来の值とどの程度 異なる值に決定されるかを調べる。以下、FE解析結果 に山川の解を適用して推定される $D$ および $a$ を、それ ぞれ $D_{e s t}, a_{e s t}$ とする。

4.4 .1 節で示したように、 $r_{M A X(Y M K)}$ は $a / D$ にかかわ らず $0.7071 D$ で一定であるが、 $r_{M A X(F E M)}$ は $a / D=0.3$ 付 近から $0.7071 D$ より小さくなる。このことから、D $D_{\text {est }}$ は 必然的に本来の值より浅く求められることになる。例 えば、 $r_{M A X(F E M)}$ が $0.3903 D$ まで小さくなる $a / D=0.9$ の 場合に(5)式を適用すると、 $D_{\text {est }}$ は $0.5520 D$ と、本来の 深さ $(D)$ の半分近くにまで浅く見積もられることにな る。

これと同様のことは最小二乗法を用いる場合にも言 える。 $U_{z(F E M)}$ と $U_{r(F E M)}$ のそれぞれに最小二乗法を適用 し、FEモデルと同じ $\Delta P$ および $\mu$ を仮定すると、 $D_{\text {est }}$ お よび $a_{e s t}$ を同時に決定することができる。各 $\mathrm{FE}$ モデル の $U_{z(F E M)}$ と $U_{r(F E M)}$ から求められた $D_{e s t}$ および $a_{e s t}$ を Fig.12 および Table4 に示す（ $D_{\text {est }}$ については各 FE モデ ルの $D$ で、また、 $a_{\text {est }}$ については $a=1 \mathrm{~km}$ で規格化）。 ただし、ここでは、全ての FE モデルについて距離 $r=$ $1.5 D$ までの $U_{z(F E M)}$ および $U_{r(F E M)}$ を用いて $D_{e s t}$ および $a_{e s t}$ を決定した。これは、遠方のデータを多く含めると それらの影響が強くなり、最小二乗法によって決定さ れた山川の解の変位曲線が $U_{z M A X}$ 付近および $U_{r M A X}$ 付近 において FE 解析結果とあまり良く一致しなくなるた めである。

さて、Fig.12 および Table4 より、 $a / D=0.1$ および 0.2 の場合は、 $D_{e s t}$ および $a_{e s t}$ とも元の FE モデルとほぼ同 じ值に決定されることが分かる。 $a / D$ が 0.3 以上になる と、 $D_{\text {est }}$ は真の值より小さく（つまり浅く）決定される ようになるが、 $U_{z(F E M)}$ による值と $U_{r(F E M)}$ による值は常 


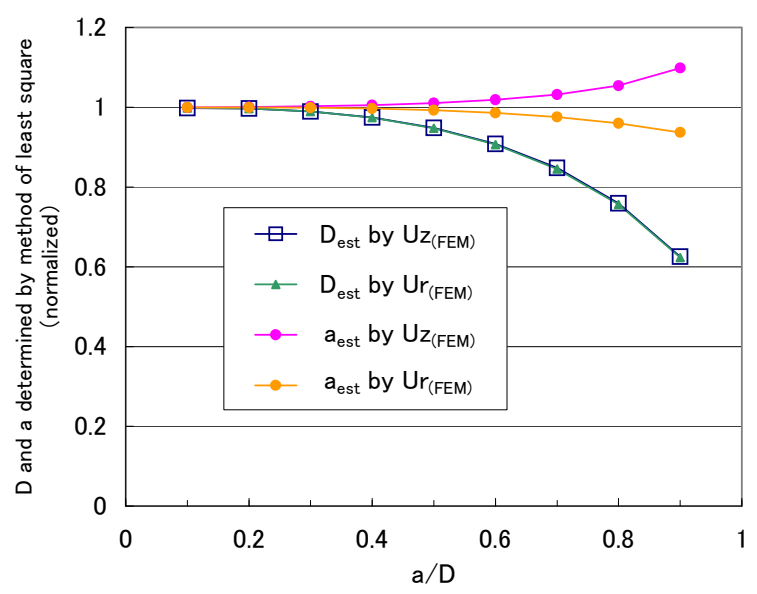

Fig. $12 D$ and $a$ determined by the method of least squares, fitting Yamakawa's solution to $U_{z(F E M)}$ and $U_{r(F E M)}$. Only nearby data $(r \leqq 1.5 D)$ were used to determine these values.

にほぼ同じ值となり、 $a / D=0.9$ の場合はいずれも $0.62 D$ 程度に決定される。一方、 $a_{\text {est }}$ については、 $a / D$ が 0.5 以下の場合は真の值と約 $1 \%$ 以内の精度で決定される が、 $a / D$ が 0.6 以上になると、 $U_{z(F E M)}$ による值は真の值 より若干大きく決定されるようになり、 $U_{r(F E M)}$ による 值については逆の傾向を示す。しかしながら、真の值 との違いは $a / D=0.9$ の場合でもいずれも $10 \%$ 以下と、 $D_{\text {est }}$ の場合に比べて小さい。

以上のように、もし $a / D$ が大きな球圧力源が現実に 存在する場合、それによる地表面変位に山川の解を適 用すると、 $D$ は真の值よりも過剰に浅く決定されるが、 $a$ は真の值に比較的近い值に決定される。今、FE モデ ルと同じ $\Delta P$ および $\mu$ を仮定しているので、(9)式より、 $\Delta V$ も比較的正確に見積もることができることになる。 $a$ は(9)式中に 3 乗の形で入っているため、 $a$ の僅かな誤 差が $\Delta V$ の見積もりに大きく影響してくるが、Table4 の $a_{e s t}$ から $\Delta V$ を算出した場合、その見積もり誤差は $D_{\text {est }}$ のそれより小さい。

\section{6. まとめ}

地下に存在する球圧力源の半径 $a$ が深さ $D$ に比して 大きい場合の地表面変位の特徵を明らかにするため、 FEM を用いて数值計算を行った。また、その結果を、 厳密には $a / D$ が充分小さい場合にしか成立しない山川

（1955）の解や、 $a / D$ が大きい場合にも適用できるとさ れる McTigue（1987）の解と比較した。これにより、 以下のような知見が得られた。

$1 ） a / D$ を次第に大きくしていった場合、山川の解 は早い時点で FE解析結果と食い違うようになる。また、 McTigue の解についても限界が存在する。変位曲線全 体について見た場合、FE 解析結果に $1 \%$ 以内で一致す る $a / D$ の值は、山川の解で 0.22 , McTigue の解で 0.45 である。 $a / D$ がこれより大きくなると、 2 つの解析解と FE 解析結果との食い違いは次第に顕著になる。

$2 ） a / D$ が大きくなるにつれ、水平変位 $U_{r}$ は、山川 の解や McTigue の解によって表される地点よりも球圧 力源直上に近い地点で最大值を取るようになる。

3 ） $a / D$ が大きくなるにつれ、 $U_{z}$ および $U_{r}$ の最大值 は、2つの解析解によって表される值より大きくなる。 その度合いは $U_{r}$ よりも $U_{z}$ の方が大きい。

4 ） $a / D$ の大小にかかわらず、地表面の任意の地点 は、球圧力源中心とその地点とを結ぶ延長線上に変位 する。従って、地表面上の 2 点において変位ベクトル が得られれば、それらの延長線が交わった点が球圧力 源の中心となる。

5 ） FE 解析結果に山川の解を適用して $D$ および $a$ を決定すると、 $a / D$ が大きくなった場合、 $D$ は真の值よ りも過剩に浅く決定される。一方、 $a$ は真の值に比較的 近い值に決定され、従って球圧力源の体積変化量 $\Delta V$ も比較的正確に見積もることができる。

なお、本稿では、FE モデルの剛性率 $\mu$ の值として上 部地殼の標準的な值 $40 \mathrm{GPa}$ を用いたが、標準的な上部 地款に比べて一般に地震波速度が遅い火山の山体の剛 性率はこれより低い值であると考えられることに注意 が必要である。剛性率を低くした場合、変位量は剛性 率に反比例して増大する。

Table $4 \quad D$ and $a$ determined by the method of least squares shown in Fig.12.

\begin{tabular}{c|c|c|c|c}
\hline \hline \multirow{2}{*}{$a / D$} & \multicolumn{4}{|c}{ Values determined by method of least squares } \\
\cline { 2 - 5 } & \multicolumn{2}{|c}{ normalized by $D$} & normalized by $a(=1 \mathrm{~km})$ \\
\cline { 2 - 5 } & $D_{e s t}$ by $U_{z(F E M)}$ & $D_{e s t}$ by $U_{r(F E M)}$ & $a_{e s t}$ by $U_{z(F E M)}$ & $a_{e s t}$ by $U_{r(F E M)}$ \\
\hline 0.1 & 0.9978 & 0.9985 & 0.9993 & 0.9992 \\
0.2 & 0.9967 & 0.9966 & 1.0005 & 0.9995 \\
0.3 & 0.9893 & 0.9891 & 1.0022 & 0.9986 \\
0.4 & 0.9743 & 0.9738 & 1.0053 & 0.9966 \\
0.5 & 0.9484 & 0.9474 & 1.0104 & 0.9925 \\
0.6 & 0.9079 & 0.9062 & 1.0187 & 0.9858 \\
0.7 & 0.8475 & 0.8450 & 1.0317 & 0.9754 \\
0.8 & 0.7591 & 0.7562 & 1.0539 & 0.9598 \\
0.9 & 0.6258 & 0.6232 & 1.0981 & 0.9368 \\
\hline
\end{tabular}




\section{謝辞}

気象研究所地震火山研究部の伊藤秀美部長 (現沖縄 気象台長）からは本稿の執筆に際して終始お励ましを 頂き、また原稿に対して貴重なご意見を頂きました。 厚くお礼申し上げます。同研究部の山里 平室長およ び北川貞之氏（現気象庁）には原稿を丁寧に読んで頂 き、適切なコメントを頂きました。2 名の匿名査読者 および編集委員の山本剛靖氏からのご指摘は本稿の改 善にとって非常に有益でした。以上の方々に深く感謝 致します。本研究は気象研究所特別研究「火山活動評 価手法の開発研究」（平成 13～17 年度）に関連して行 なわれたものです。特別研究の実施に際してお世話頂 きました関係諸官に謝意を表します。

\section{参考文献}

萩原幸男, 1977 : 伊豆大島の異常隆起を説明する茂木モデ ルとそれに伴う重力変化. 東京大学地震研究所彙報, 52, 301-309.

小柴正則, 1990 : 光・波動のための有限要素法の基礎. 森 北出版, $227 \mathrm{pp}$.

茂木清夫, 1957 : 桜島の噴火と周辺の地殼変動との関係. 火山, 1, 9-18.

坂井孝行 - 山本哲也 - 福井敬一 - 藤原健治 - 高木朗充 - 中 禮正明, 2007 : 有限要素法による火山性地凯変動の計 算精度の確立一茂木-山川モデルの再現一。気象研究 所研究報告， 58, 1-15.

山川宜男, 1955 : 内部力源による半無限弾性体の変形につ いて。地震，8，84-98.

McTigue, D. F., 1987: Elastic stress and deformation near a finite spherical magma body: resolution of the point source paradox. J. Geophys. Res., 92-B12, 12931-12940.

\title{
深さに比して相対的に大きな半径を有する球圧力源による地表面変位 一有限要素法による計算一
}

\author{
坂井孝行 (気象研究所地震火山研究部) ・ 山本哲也* $($ 気象庁 $)$ \\ 福井敬一 (気象研究所地震火山研究部) ・藤原健治 (気象庁) \\ 高木朗充 (気象研究所地震火山研究部) - 中禮正明 ${ }^{*}$ (新潟地方気象台)
}

\begin{abstract}
火山における地殼変動を解釈寸るモデルとして、従来、山川（1955）の解析解に基づく「茂木-山川モデル」（または、単に 「茂木モデル」）が多く用いられてきた。山川の解は、深さに対して充分小さな球圧力源が半無限均質弾性体内に存在すると いう、限定された条件下においてのみ成立寸る解であるが、球圧力源の深さ $D$ に対する半径 $a$ がどの程度の場合まで山川の解 が精度良く成立寸るのかについては、定量的な検証はこれまでほとんどなされていない。一方、McTigue（1987）による解析 解は、山川の解を $a / D$ が大きい場合にも適用できるよう修正したものであるが、この解についても山川の解と同様、適用限界

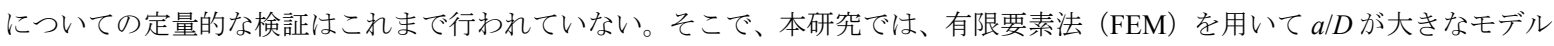
を作成し、地表面変位の数值解を求め、2つの解析解との比較を行った。その結果、2つの解析解の適用限界が明らかとなっ た。例えば、FE解析結果に $1 \%$ 以内で一致寸る $a / D$ の值は、山川の解で 0.22 , McTigue の解で 0.45 であることが判明した。a/D

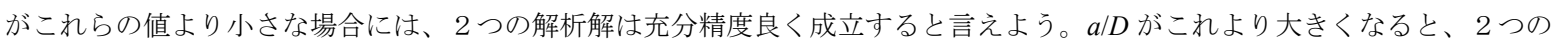
解析解と FE 解析結果との食い違いは次第に顕著になっていく。一方、FE解析結果に山川の解を適用して $D$ および $a$ を決定す ると、 $a / D$ が大きくなった場合、 $D$ は真の值よりも過剩に浅く決定されるが、 $a$ は真の值に比較的近い值に決定され、従って、 圧力源の体積変化量 $\Delta V$ も比較的正確に見積もることができる。
\end{abstract}

* 現所属 : 地磁気観測所 